\title{
Economics
}

The Open-Access, Open-Assessment E-Journal

Vol. 13, 2019-42 | October 16, 2019 | http://dx.doi.org/10.5018/economics-ejournal.ja.2019-42

\section{Does fiscal consolidation hurt economic growth? Empirical evidence from Spanish regions}

\author{
Santiago Lago-Peñas, Alberto Vaquero-Garcia, Patricio Sanchez- \\ Fernandez, Beatriz Lopez-Bermudez
}

\begin{abstract}
This article brings empirical evidence on the effect of fiscal consolidation in decentralized countries. The focus on Spain is justified by three reasons. First, it is one of the OECD countries most affected by the Great recession in terms of both GDP and public deficit. Second, Spain is one of the most decentralized countries in the world. Third, compliance with fiscal consolidation targets has been very diverse across regions. Using both time series econometrics and the Synthetic Control Method approach (SCM), we show that compliance with fiscal targets at the regional level has not involved lower GDP growth rates in the short-run. Openness and economic integration of regional economies involve that fiscal multipliers tend to fade. Hence, while a fiscal stimulus would not work on this scale, the opposite is also true: the potentially negative demand effects of a stronger regional fiscal consolidation strategy would be exported to other regions.
\end{abstract}

JEL H74 R11 H62

Keywords Fiscal consolidation; regional economic growth; Great recession

\section{Authors}

Santiago Lago-Peñas, GEN (University of Vigo), gen@uvigo.es

Alberto Vaquero-Garcia, GEN (University of Vigo)

Patricio Sanchez-Fernandez, GEN (University of Vigo)

Beatriz Lopez-Bermudez, GEN (University of Vigo)

Citation Santiago Lago-Peñas, Alberto Vaquero-Garcia, Patricio Sanchez-Fernandez and Beatriz Lopez-Bermudez (2019). Does fiscal consolidation hurt economic growth? Empirical evidence from Spanish regions. Economics: The Open-Access, Open-Assessment E-Journal, 13 (2019-42): 1-19. http://dx.doi.org/10.5018/economics-ejournal.ja.2019-42

Received March 25, 2019 Published as Economics Discussion Paper May 7, 2019 Revised September 27, 2019 Accepted October 8, 2019 Published October 16, 2019

(c) Author(s) 2019. Licensed under the Creative Commons License - Attribution 4.0 International (CC BY 4.0) 


\section{$1 \quad$ Motivation}

The Great Recession revived the long-standing debate between Keynesians and "supply-side" scholars (Andrés and Doménech, 2013), and it reopened the discussion on the relevance of fiscal multipliers and the effect of fiscal consolidation on GDP growth in the short-run. Researchers are still divided between those who affirm that fiscal consolidation can end up producing expansive effects (Giavazzi and Pagano, 1990; Alesina and Ardagna, 1998 and 2010), especially when based on expenditure cuts (Alesina et al., 2019), and those who maintain that immediate fiscal austerity is counterproductive for economies (Blanchard and Cottarelli, 2010; Blanchard and Leigh, 2013; De Grauwe and Ji, 2013; Fatàs and Summers, 2018).

A middle position outlines the importance of the initial conditions (economic and fiscal), claiming that the anticipated consolidation is better than a progressive form if the starting value of the debt/GDP ratio is huge (Nickel and Tudyka, 2013) or if the period of consolidation effort follows a financial crisis (Buti and Pench, 2012). Moreover, the cyclical situation of the economy is relevant: fiscal multipliers are significantly higher in turbulent times (Auerbach and Gorodnichenko, 2012; De Mello, 2013; Warmedinger et al., 2015; Hernández de Cos and Moral-Benito, 2016; Attinasi and Klemm, 2016).

As a consequence of this diversity, opposite estimates of fiscal multipliers are reported. Spilimbergo et al. (2009) show fiscal multipliers ranging between -1.5 and 5.2, with Corsetti et al. (2012) reducing these magnitudes to -0.7 and 2.3, and Gechert and Wil (2012) to -1.3 and 2.8 .

The divergence shows the difficulty of isolating the effects of fiscal stimulus policies from those of other factors affecting the economy: the exchange rate, monetary policy, health of public finances, availability of bank lending, and so on. In order to control by those factors, the analysis of highly decentralized countries can provide further insights into this empirical question. Comparing the performance of regions that are subject to the same macroeconomic conditions but committed to fiscal consolidation to different degrees makes the analysis much easier than comparing countries.

Furthermore, the debate on the effect of decentralization on fiscal stability of countries is still open (Lago-Peñas et al, 2019). Looking at the growth effects of regional fiscal consolidations may also help to shed additional light on this debate. This is the second target of this article.

Insofar as this empirical analysis requires strong expenditure decentralization, a regional capacity to enter into debt and a substantial shock affecting public finances and involving the need for fiscal consolidation, Spain is the best candidate among the OECD members.

In short, our analysis is based on the short-run GDP dynamics of the regional leader in the compliance with fiscal consolidation targets (Galicia) and compares the observed GDP growth rates with what would have happened with softer regional fiscal consolidation. Two complementary analyses are carried out. In Section 3, we perform a time-series econometric analysis and compare the observed GDP growth rates with a forecast. In Section 4, we rely on the more sophisticated synthetic control method (SCM) approach to make the comparison. Section 5 concludes. 


\section{The fiscal adjustment in Spain and the case of Galicia}

Spain is one of the most decentralized countries in the world (Lago-Peñas et al., 2017). In terms of the share of sub-national (both local and regional) in total public expenditure, it ranks fifth in the OECD. ${ }^{1}$ If the attention focuses on the regional tier, Spain tops the ranking for the European Union (EU), with figures similar to those of Canada and Switzerland. Moreover, the impact of the Great Recession on the deficit and debt in Spain has been huge. Public debt rose from 36\% of the GDP in 2007 to 100\% (Lago-Peñas, 2017).

While the economic crisis struck the GDP growth rates of all regions (Figure 1) and the deficit expanded in all cases, there are significant differences in the implementation of budget consolidation and thus the meeting of the fiscal targets agreed with the European Commission.

Figure 1: GDP real growth rates

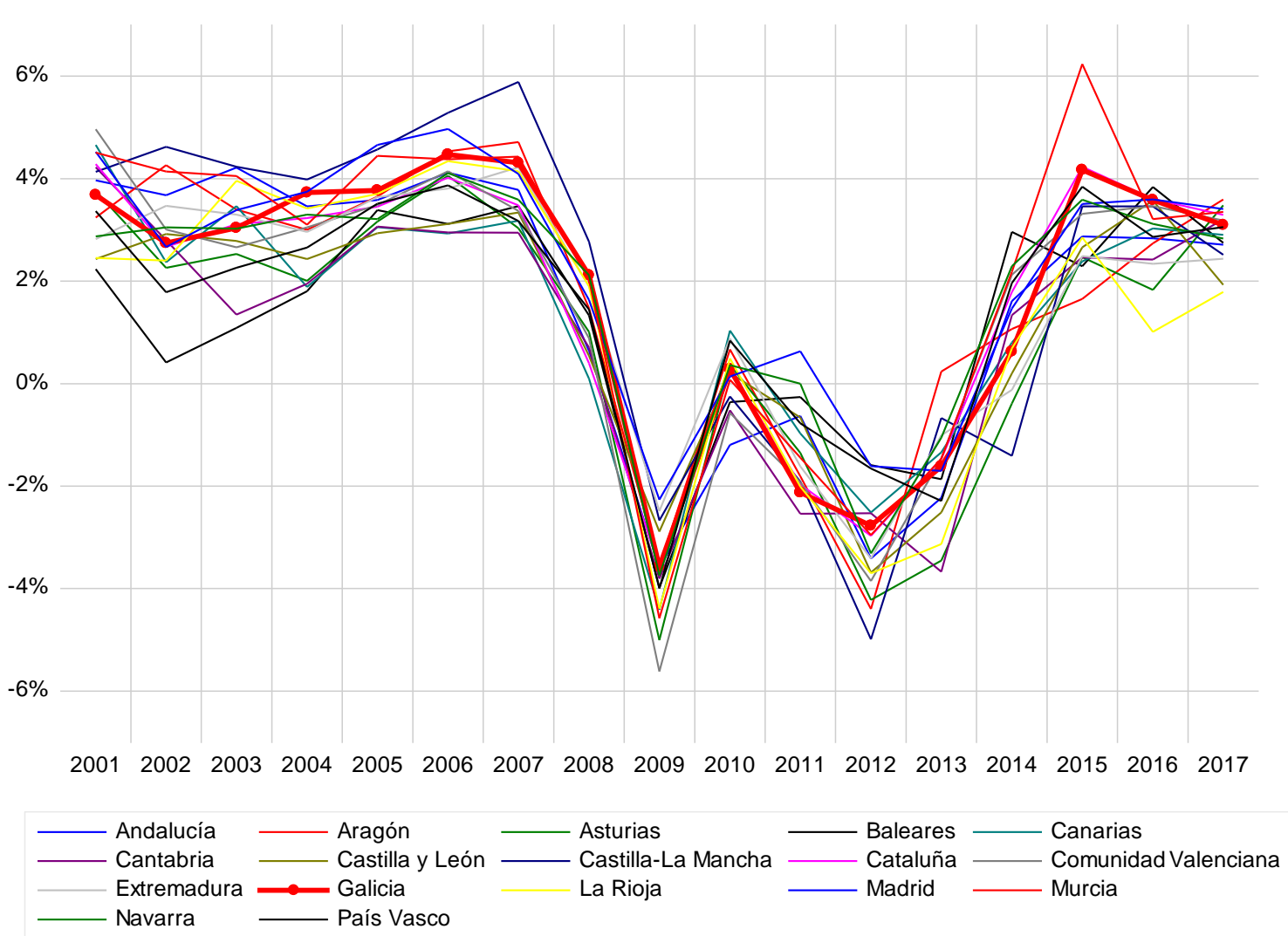

Source: Authors' elaboration using data from the INE (2018).

1 Furthermore, according to the Regional Authority Index, computed by Hooghe et al. (2016) (http://garymarks.web.unc.edu/data/regional-authority/), Spain was second in the last year available (2010). Only Germany shows a higher score. The sample consists of all the EU member states, all the member states of the OECD, all the Latin American countries, ten countries in Europe beyond the EU and eleven countries in the Pacific and South-East Asia. 
Figures 2 and 3 show the evolution of the regional average deficit and debt over the period 2008 to 2017. The regional deficit increased substantially to exceed -3\% of the GDP in 2010 and 2011. Correspondingly, public indebtedness rose from less than 7\% of the GDP in 2008 to almost 25\% in 2017. The figures for Galicia are significantly lower for both deficit and debt.

Lago-Peñas and Vaquero (2016) and Lago-Peñas et al. (2017) demonstrate that the evolution of deficits and fiscal consolidation efforts differed significantly across regions. Table 1 summarizes the non-compliance of fiscal targets by Spanish regional governments over the period 2009-2016. Fiscal targets include the deficit target expressed in terms of regional GDP, a constraint on total spending growth (the so called-“spending rule”), and a debt target expressed again in terms of regional GDP. ${ }^{2}$ In spite of a drop in the total revenues over the average, ${ }^{3}$ Galicia stands out as the region with the highest degree of fulfilment. ${ }^{4}$

Finally, the available evidence shows that spending cuts account for the lion's share of fiscal consolidation in all the regions (MINHAP, 2012; Cantalapiedra and López, 2013). Taking into account increases in both tax rates and tax benefits, the net average effect is neutral (AIReF, 2016), with some regions in negative figures (especially Madrid and Cantabria, due to tax cuts in wealth taxes). For the case of Galicia, the net effect is positive but small. In 2016, the contribution of net tax increases to fiscal stability was equivalent to $0.2 \%$ of the regional GDP.

Figure 2: Regional public deficit dynamics. Values in percentage of GDP

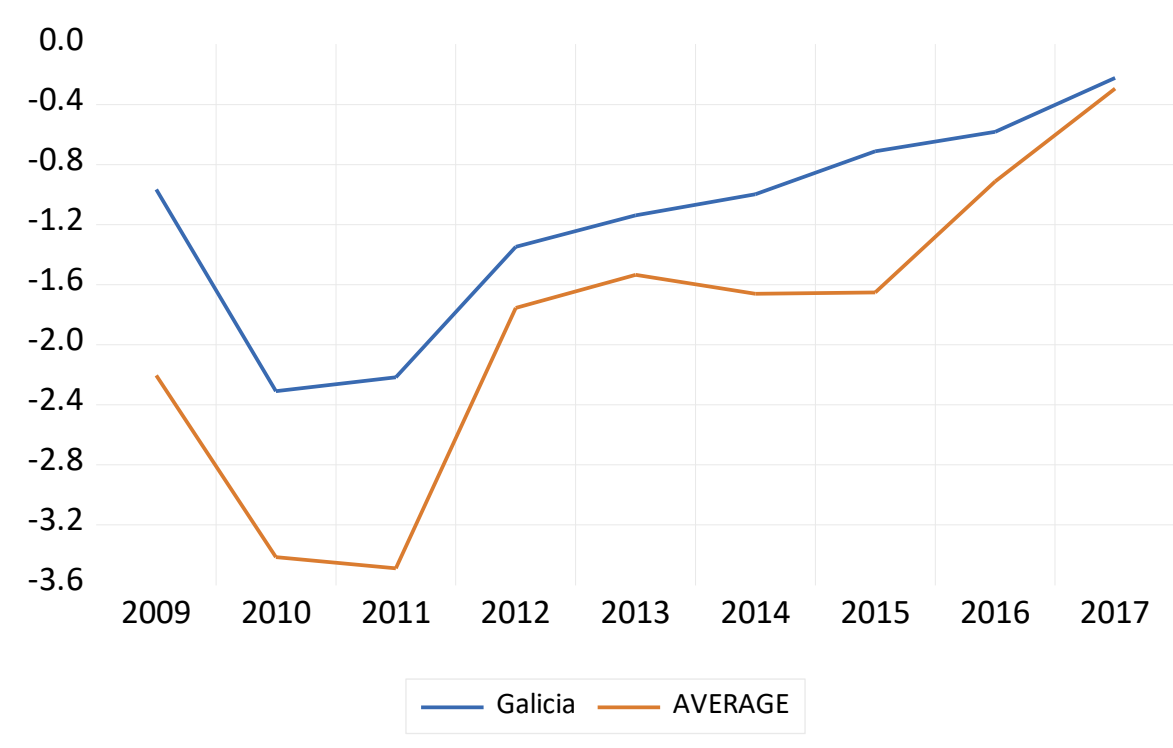

Source: Authors' elaboration using data from the IGAE (2018)

\footnotetext{
2 See Rodríguez and Cuerpo (2018) for an analysis on fiscal targets implemented in Spain according to the European Union guidelines.

3 The regions where both the total revenues and the total expenditure dropped more than the regional average are Galicia, Baleares, Castilla y Leon, Extremadura, Navarra and Andalucía.

${ }^{4}$ Lago-Peñas and Vaquero (2016) identify several clusters according to the dynamics of deficit. The members of the leader group are Galicia, Madrid and Canarias. In contrast, the regions in the cluster with the worst results are Murcia, Comunidad Valenciana, Cataluña and Baleares.
} 
Figure 3: Regional debt stock. Values in percentage of GDP

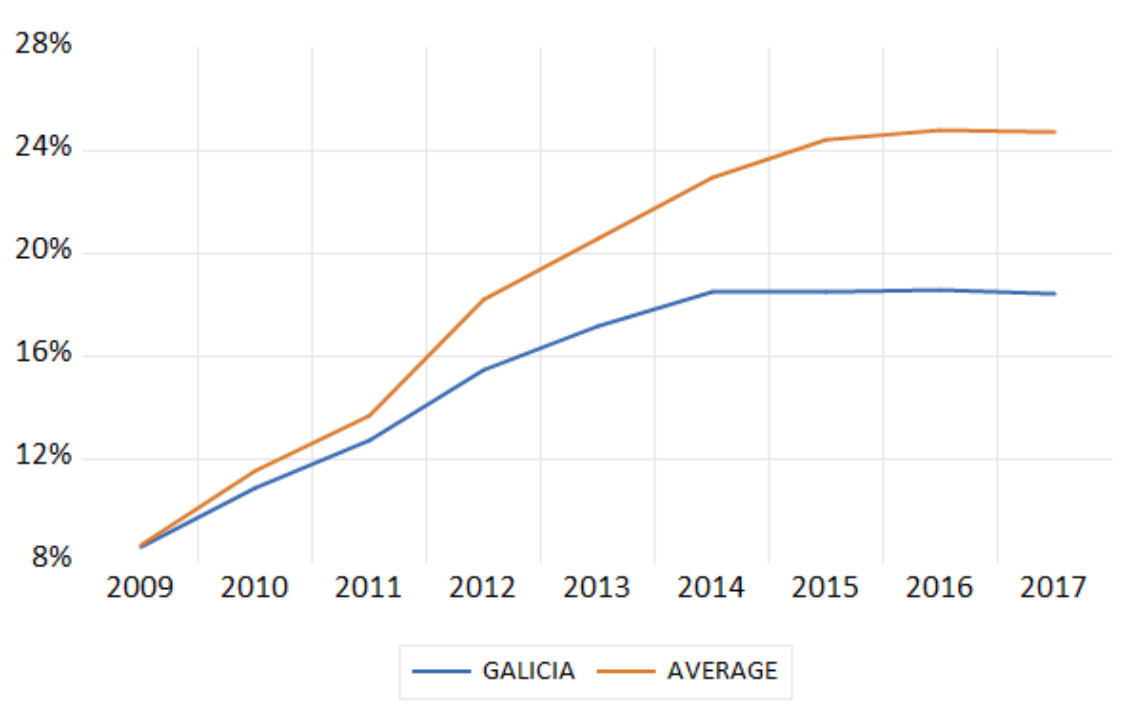

Source: Authors' elaboration using data from the Bank of Spain (2018)

When looking for the reasons explaining this better fiscal performance of Galicia, two related factors clearly emerge: the electoral cycle and political will. Regarding the first factor, four Spanish regions enjoy an asymmetrical electoral cycle: Galicia, País Vasco, Cataluña and Andalucía. The acknowledgement by the Spanish central government of the effect of the international economic crisis occurred in summer 2008. In March 2009, elections were held in Galicia and País Vasco. The following elections were in Cataluña in November 2010 and in the remaining regions in May 2011 (and March 2012 in Andalucía). Concerning the second factor, the new conservative Galician incumbent replaced a leftist coalition and made fiscal austerity the main political message of its political campaign. Hence, the new government took advantage of the timing of the election to adapt the regional budget to the new economic scenario. Regional expenditure cuts started in 2009 and intensified in 2010. Since then, austerity has been the cornerstone of political will of the regional president and ministers, including more exigent measures than in most regions, like the cut in civil servants' wages approved in 2013 and extended until 2017. Surprisingly, and in sharp contrast to the electoral results in other regions and countries, the political support for the Galician incumbent increased in the 2012 and 2016 elections.

To analyse the effect on growth of the stronger fiscal consolidation process carried out in Galicia, two complementary methodologies are used: a standard econometric approach based on a dynamic time-series model (Section 3) and the synthetic control method originally proposed by Abadie and Gardeazabal (2003) in Section 4. In both cases, we compare two series: the observed GDP growth rate affected by cross-regional asymmetries in the intensity of fiscal consolidation since 2009 and the simulated GDP growth rate from extrapolating the structural relationship before 2009 . 
Economics: The Open-Access, Open-Assessment E-Journal 13 (2019-42)

Table 1: Regional non-compliance with fiscal targets (2009-2016)

\begin{tabular}{|c|c|c|c|c|c|c|c|c|c|c|c|c|c|c|c|}
\hline \multirow{2}{*}{ Regions } & \multicolumn{8}{|c|}{ Non-compliance with deficit targets } & \multicolumn{3}{|c|}{$\begin{array}{l}\text { Non-compliance with } \\
\text { the spending rule }\end{array}$} & \multicolumn{4}{|c|}{$\begin{array}{c}\text { Non-compliance with the } \\
\text { debt target }\end{array}$} \\
\hline & 2009 & 2010 & 2011 & 2012 & 2013 & 2014 & 2015 & 2016 & 2014 & 2015 & 2016 & 2013 & 2014 & 2015 & 2016 \\
\hline Andalucía & $x$ & $x$ & $x$ & $x$ & & $x$ & $x$ & & & $x$ & $x$ & & & & \\
\hline Aragon & $x$ & $x$ & $x$ & & $x$ & $x$ & $x$ & $x$ & & $x$ & & $x$ & $x$ & & \\
\hline Asturias & $x$ & $x$ & $x$ & & & $x$ & $x$ & & & $x$ & & & & $x$ & \\
\hline Baleares & $x$ & $x$ & $x$ & $x$ & & $x$ & $x$ & $x$ & $x$ & & & & & & \\
\hline Canarias & $x$ & & $x$ & & & & & & $x$ & & $x$ & & & & \\
\hline Cantabria & $x$ & $x$ & $x$ & $x$ & $x$ & $x$ & $x$ & $x$ & & $x$ & & & & & \\
\hline $\begin{array}{l}\text { Castilla-La } \\
\text { Mancha }\end{array}$ & $x$ & $x$ & $x$ & $x$ & $x$ & $x$ & $x$ & $x$ & & $x$ & & $x$ & & & \\
\hline $\begin{array}{l}\text { Castilla y } \\
\text { Leon }\end{array}$ & $x$ & & $x$ & & & $x$ & $x$ & & & $x$ & & & $x$ & & \\
\hline Cataluña & $x$ & $x$ & $x$ & $x$ & $x$ & $x$ & $x$ & $x$ & $x$ & $x$ & & & & & \\
\hline $\begin{array}{l}\text { Comunidad } \\
\text { Valenciana }\end{array}$ & $x$ & $x$ & $x$ & $x$ & $x$ & $x$ & $x$ & $x$ & $x$ & $x$ & & & & & \\
\hline Extremadura & $x$ & & $x$ & & & $x$ & $x$ & $x$ & $x$ & $x$ & & & & & \\
\hline Galicia & & & $x$ & & & & & & & & $x$ & & & & \\
\hline Madrid & & & $x$ & & & $x$ & $x$ & & $x$ & $x$ & & & & & \\
\hline Murcia & $x$ & $x$ & $x$ & $x$ & $x$ & $x$ & $x$ & $x$ & & $x$ & $x$ & & & & \\
\hline Navarra & $x$ & $x$ & $x$ & $x$ & $x$ & & $x$ & & & $x$ & & $x$ & & & \\
\hline País Vasco & $x$ & & $x$ & & & & & & $x$ & & $x$ & & & & \\
\hline La Rioja & & $x$ & $x$ & & & $x$ & $x$ & & & $x$ & & & $x$ & & \\
\hline
\end{tabular}

Source: $\operatorname{AIReF}(2018)$

\section{Empirical analysis I: A standard econometric approach}

The departure point of the first econometric analysis is the following AR (2) model:

$$
\mathrm{GAL}_{\mathrm{t}}=\beta_{0}+\beta_{1} \operatorname{SPAIN}_{\mathrm{t}}+\beta_{2} \mathrm{GAL}_{\mathrm{t}-1}+\beta_{3} \mathrm{GAL}_{\mathrm{t}-2}+\varepsilon_{\mathrm{t}}
$$

In Equation (1), the variables GAL and SPAIN are inter-annual real GDP growth rates of Galicia and Spain, respectively. ${ }^{5}$ The data for the former are from the Galician Institute of Statistics (www.ige.eu), and the data for Spain are from the National Institute of Statistics (www.ine.es). In both cases, we rely on the quarterly seasonally adjusted data provided on the websites. We use Eviews 10.5 for the econometric estimates.

The estimation period is 1996:Q1 to 2008:Q4. The selection of the starting point is based on the evidence provided by Lago-Peñas (2001), who shows that the synchrony of the Spanish and

\footnotetext{
5 Defined as the variation of GDP in each quarter in relation to the same quarter of the previous year.
} 
Galician business cycles has substantially converged since the early 1990s. Therefore, the goodness of fit will tend to be significantly higher, while the sample size is large enough to perform estimates. Two lags for the variable GAL are enough to capture the dynamics. ${ }^{6}$ To rule out specification problems, we perform two complementary tests on the specification. First, a Hausman test on the endogeneity of the variable SPAIN's p-value of the corresponding Wald test is high (p-value $=0.25$ ) and thus the null hypothesis of exogeneity is not rejected. ${ }^{7}$ Second, a Granger causality test is performed to verify the causation order. The results in Table 2 clearly show that we can reject the null hypothesis of no causation from SPAIN to GAL (pvalue $<0.001$ ) but not the opposite causation ( $\mathrm{p}$-value $=0.88$ ).

Table 3 reports the ordinary least squares (OLS) estimate of Equation (1). The fit is good $\left(\mathrm{R}^{2}=0.853\right)$. The null hypothesis of no autocorrelation cannot be discarded according to the Breusch-Godfrey serial test ( $\mathrm{p}$-value $=0.12$ ). The corresponding correlogram yields the same conclusion. Both SPAIN and the first lag of GAL, but not the second one, are highly significant variables, with coefficients around 0.6.

Our econometric results allow us to forecast the Galician GDP growth rate from 2009 to 2017. In particular, using observed data for the variable SPAIN, we perform a dynamic forecast assuming that the relationship estimated in Table 2 will hold. Figure 4 shows both series. The observed GDP growth is clearly above the forecasted growth throughout the period 2009-2014. The sign of the differential changes at the end of 2014, when the forecasted growth exceeds the observed growth. Hence, in 2015 and 2016, the Galician GDP growth rate was slower that it should be, taking into account the recovery of the Spanish economy. The situation changes again at the end of 2016 when the two series overlap. Moreover, in 2017, the observed GDP growth rate is slightly higher than that forecasted.

In sum, looking at the whole period, the observed GDP growth rate is significantly above the forecasted rate. Hence, the data do not support the existence of a price to pay for fiscal consolidation in terms of short-run GDP growth. ${ }^{8}$

Table 2: Granger causality test. Period 1996Q1-2008Q4.

\begin{tabular}{lc}
\hline Null hypothesis & p-value \\
\hline SPAIN does not Granger cause GAL & $0.0002^{* * *}$ \\
\hline GAL does not Granger cause SPAIN & 0.89 \\
\hline
\end{tabular}

Notes: 2 lags included. *** p-value $<0.01$. Source: Authors’ elaboration.

\footnotetext{
6 Adding the first lag of SPAIN and the third one of GAL on the right-hand side does not improve the fitness, reducing the adjusted $\mathrm{R}^{2}$. According to a joint Wald test, their coefficients are not significantly different from zero (pvalue $=0.17$ ).

7 The test is implemented in two steps. First, SPAIN is regressed on its own first two lagged values and the two lagged values of GAL. The residuals obtained are included in the original equation. The null hypothesis is that they are not statistically significant.

8 This conclusion holds if we discount the most relevant positive asymmetric shock affecting the Galician economy during the period, the Jacobean year 2010. According to BBVA research (2010), the Galician GDP growth rate would have been $0.5-0.6 \%$ higher in $2010,+0.2 \%$ higher in 2011 and $+0.1 \%$ higher in 2012 thanks to the impact of the Jacobean year on tourism.
} 
Table 3: Econometric estimate of equation (1)

\begin{tabular}{cc}
\hline SPAIN & $0.65^{* * *}$ \\
& $(6.55)$ \\
\hline GAL $_{-1}$ & $0.60 * * *$ \\
$(4.45)$ \\
\hline $\mathrm{GAL}_{-2}$ & -0.11 \\
$\mathrm{R}^{2}$ & $(-0.91)$ \\
\hline Endogeneity Hausman test (p-value) & 0.853 \\
\hline B-G serial correlation LM test (p-value) & 0.25 \\
\hline Number of observations & 0.12 \\
\hline
\end{tabular}

Notes: t-statistics in parenthesis. ${ }^{* * *} \mathrm{p}$-value $<0.01$ Source: Authors’ elaboration.

Figure 4: Observed and forecasted Galician GDP growth rates using specification (1)

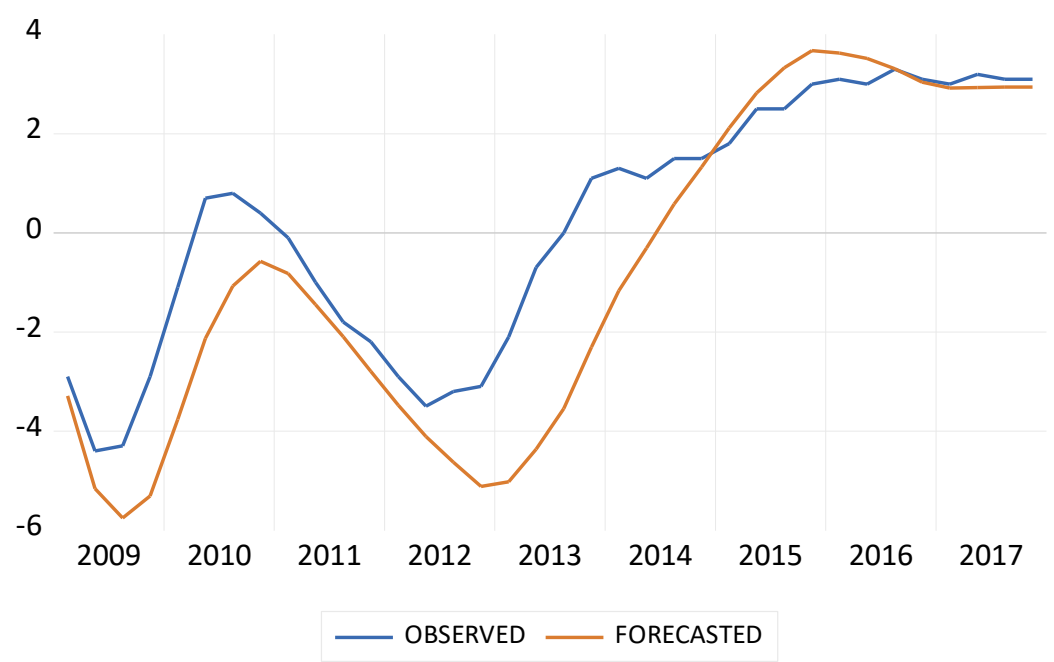

Source: Authors’ own elaboration

\section{Empirical analysis II: The synthetic control method approach}

The synthetic control method (SCM) is based on the seminal contribution by Abadie and Gardeazabal (2003), who analyse the effects of terrorism in the Basque Country. The SCM is refined in subsequent works by Abadie et al. (2010) on the effects of the anti-tobacco law in California and Abadie et al. (2015) on the costs of reunification in Germany.

The SCM analyses the consequences of a specific event or intervention in a region by comparing the observed data with what would have happened in the absence of the intervention. Insofar as it requires the creation of a counterfactual, the first step of the method is to find other similar regions that remained unaffected by the event (the comparison units) and merge them to 
create a synthetic region close to the case of interest. More formally, the SCM supposes that there are $\mathrm{J}+1$ regions or "units", where $j=1$ is the "treated unit" and units $j=2$ to $j=\mathrm{J}+1$ constitute the "donor pool" (Abadie et al., 2010: 493-505). Following Abadie et al. (2010) and Abadie et al. (2015), we assume that the sample is a balanced panel and includes a positive number of preintervention periods, $T_{0}$, as well as a positive number of post-intervention periods, $T_{1}$, with $\mathrm{T}=\mathrm{T}_{1}+\mathrm{T}_{0}$.

The synthetic control is defined as a weighted average of the units in the donor pool represented by a $(\mathrm{J} \times 1)$ vector of weights $\mathrm{W}=\left(\mathrm{W}_{2}, \ldots ., \mathrm{W}_{\mathrm{J}+1}\right)$, with $0 \leq \mathrm{W}_{\mathrm{j}} \leq 1$ for $j=2, \ldots . . \mathrm{J}$ and $\mathrm{W}_{2}+\ldots .+\mathrm{w}_{\mathrm{J}+1}=1$. Choosing a particular value for $\mathrm{W}$ is equivalent to choosing a synthetic control. Let $X_{1}$ be a $(k \times 1)$ vector containing the values of the pre-intervention characteristics of the treated unit that we aim to match as closely as possible, and let $\mathrm{X}_{0}$ be the $\mathrm{k} \times \mathrm{J}$ matrix collecting the values of the same variables for the units in the donor pool. The pre-intervention characteristics in $\mathrm{X}_{1}$ and $\mathrm{X}_{0}$ may include the pre-intervention values of the outcome variable.

The difference between the pre-intervention characteristics of the treated unit and a synthetic control is given by the vector $\mathrm{X}_{1}-\mathrm{X}_{0} \mathrm{~W}$. As in the research by Abadie et al. (2010) and Abadie et al. (2015), we select the synthetic control, $W^{*}$, that minimizes the size of this difference. This can be operationalized in the following manner. For $m=1, \ldots ., \mathrm{k}$, let $\mathrm{X}_{1 \mathrm{~m}}$ be the value of the $m$-th variable for the treated unit and let $X_{0 m}$ be a $1 \times J$ vector containing the values of the $m$-th variable for the units in the donor pool. Abadie et al. (2015) choose $\mathrm{W}^{*}$ as the value of $\mathrm{W}$ that minimizes:

$$
\sum_{m=1}^{k} v_{m}\left(X_{1 m}+X_{0 m} W\right)^{2}
$$

where $v_{m}$ is a weight that reflects the relative importance assigned to the $m$-th variables when we measure the discrepancy between $\mathrm{X}_{1}$ and $\mathrm{X}_{0} \mathrm{~W}$. Of course, it is crucial that the synthetic control closely reproduces the values that the variables with large predictive power over the outcome of interest take for the treated unit. Accordingly, those variables should be assigned large $\mathrm{v}_{\mathrm{m}}$ weights. In the empirical application below, we apply a cross-validation method to choose $\mathrm{v}_{\mathrm{m}}$.

Let $Y_{j t}$ be the outcome of unit $j$ at time $t$. In addition, let $Y_{1}$ be a $\left(T_{1} \times 1\right)$ vector collecting the postintervention values of the outcome for the treated unit. That is, $Y_{1}=\left(Y_{1 T 0}+1, \ldots, Y_{1 T}\right)^{\prime}$. Similarly, let $\mathrm{Y}_{0}$ be a $\left(\mathrm{T}_{1} \times \mathrm{J}\right)$ matrix, where column $\mathrm{j}$ contains the post-intervention values of the outcome for unit $j+1$. The synthetic control estimator of the effect of the treatment is given by the comparison of post-intervention outcomes between the treated unit, which is exposed to the intervention, and the synthetic control, which is not exposed to the intervention, $\mathrm{Y}_{1}-\mathrm{Y}_{0} \mathrm{~W}^{*}$. That is, for a post-intervention period $t$ (with $t \geq \mathrm{T}_{0}$ ), the synthetic control estimation of the effect of the treatment is given by the comparison between the outcome for the treated unit and the outcome for the synthetic control in that period:

$$
Y_{1 t}-\sum_{j=2}^{J+1} w_{j}^{*} Y_{j t}
$$

The matching variables in $\mathrm{X}_{0}$ and $\mathrm{X}_{1}$ are meant to be predictors of post-intervention outcomes. These predictors are themselves not affected by the intervention. To choose the 
weights $v_{m}$ in Equation (2), a cross-validation technique is used, following Abadie et al. (2015); these weights minimize the root mean square prediction error:

$$
R M S P E=\left(\frac{1}{T_{0}} \sum_{t=1}^{T_{0}}\left(Y_{1 t}-\sum_{j=2}^{J+1} w_{j}^{*} Y_{j t}\right)^{2}\right)^{1 / 2}
$$

In our case, the variables used for the SCM are reported in Table 4. We include variables on demography, the labour market, human capital, physical capital (both public infrastructure and private), exports and foreign investment inflows, poverty (AROPE), competitiveness (the Regional Competitive Index or RCI computed by the European Commission) and the sectorial structure. While in most cases we use average values over the pre-treatment period, data for the year 2008 are used for some variables. ${ }^{9}$ The sample covers the period 1995-2016 for the 17

Table 4: SCM variables

\begin{tabular}{|c|c|c|}
\hline Variable & Definition & Database \\
\hline Per capita GDP & $\begin{array}{l}\text { Regional per capita GDP expressed in \% of Spanish } \\
\text { per capita GDP in } 2008\end{array}$ & FEDEA (2018) \\
\hline Population & $\begin{array}{l}\text { Share of regional population over total Spanish } \\
\text { population }\end{array}$ & INE (2018) \\
\hline Variation of population & Annual variation rate of regional population & INE (2018) \\
\hline Population over 64 & Share of population over 64 years old & INE (2018) \\
\hline Secondary education & Share of active population with secondary level studies & IVIE (2018a) \\
\hline Superior education & Share of active population with higher level studies & IVIE (2018a) \\
\hline Employment & Employed over population between 16 and 64 & FEDEA (2018) \\
\hline Unemployment & Unemployment rate & FEDEA (2018) \\
\hline AROPE & Rate of risk of poverty or social exclusion in 2008 & INE (2018) \\
\hline Private capital stock & $\begin{array}{l}\text { Stock of private productive capital in 2008. Figures in } \\
\text { thousands of constant euro base } 2010 \text { per employee. }\end{array}$ & IVIE (2018b) \\
\hline Public capital stock & $\begin{array}{l}\text { Stock of public productive capital in 2008. Figures in } \\
\text { thousands of constant } 2005 \text { base euro per employee. }\end{array}$ & IVIE (2018b) \\
\hline Primary sector & Share of primary sector over total GDP & INE (2018) \\
\hline Industry & Share of industry over total GDP & INE (2018) \\
\hline Construction & Share of construction over total GDP & INE (2018) \\
\hline Services & Share of services over total GDP & INE (2018) \\
\hline Exports & Exports over GDP & DataComEx (2018) \\
\hline Foreign Investment & Foreign investment received over GDP & DataInvEx (2018) \\
\hline RCI & $\begin{array}{l}\text { Regional competitiveness index in } 2008 \text { computed by } \\
\text { the European Commission }\end{array}$ & EC (2018) \\
\hline
\end{tabular}

Source: Average values over the period 1995-2008, unless expressly indicated. Authors’ elaboration.

\footnotetext{
${ }^{9}$ In the case of variable AROPE and the RCI due to availability of data. In the case of both private and public capital because of the stock nature of variables.
} 
Spanish regions. We choose the weights $\mathrm{v}_{\mathrm{m}}$ to minimize the root mean square prediction error over the validation period. Table 5 shows the computed weights, which are those used to create the "synthetic Galicia", for which the values are collected together with the corresponding actual values in Table 6.

Table 5: SCM regional weights

\begin{tabular}{|l|c|}
\hline Region & Weight \\
\hline Andalucía & 0.01 \\
\hline Aragon & 0 \\
\hline Asturias & 0.01 \\
\hline Baleares & 0 \\
\hline Canarias & 0 \\
\hline Cantabria & 0.03 \\
\hline Castilla y Leon & 0.51 \\
\hline Castilla-La Mancha & 0.16 \\
\hline Cataluña & 0.14 \\
\hline Comunidad Valenciana & 0 \\
\hline Extremadura & 0.14 \\
\hline Madrid & 0 \\
\hline Murcia & 0 \\
\hline Navarra & 0 \\
\hline País Vasco & 0 \\
\hline La Rioja & 0 \\
\hline
\end{tabular}

Source: Authors' elaboration.

Table 6: SCM estimation results

\begin{tabular}{|l|c|c|}
\hline & Galicia & Synthetic Galicia \\
\hline Per capita GDP & 0.87 & 0.91 \\
\hline Population & 0.065 & 0.065 \\
\hline Variation of population & 0.00083 & 0.0049 \\
\hline Population over 64 & 0.21 & 0.20 \\
\hline Secondary education & 63.03 & 64.96 \\
\hline Superior education & 8.52 & 8.97 \\
\hline Employment & 0.58 & 0.60 \\
\hline Unemployment & 0.079 & 0.079 \\
\hline AROPE & 25.10 & 24.03 \\
\hline Private capital stock & 83,012 & 94,985 \\
\hline Public capital stock & 3,345 & 3,396 \\
\hline Primary sector & 0.051 & 0.063 \\
\hline Industry & 0.20 & 0.19 \\
\hline Construction & 0.11 & 0.10 \\
\hline Services & 0.64 & 0.64 \\
\hline Exports & 0.11 & 0.11 \\
\hline Foreign Investment & 0.0070 & 0.0067 \\
\hline RCI & 45.20 & 43.65 \\
\hline
\end{tabular}

Source: Authors' elaboration. 
Figure 5: Observed and SCM forecasted Galician GDP growth rates

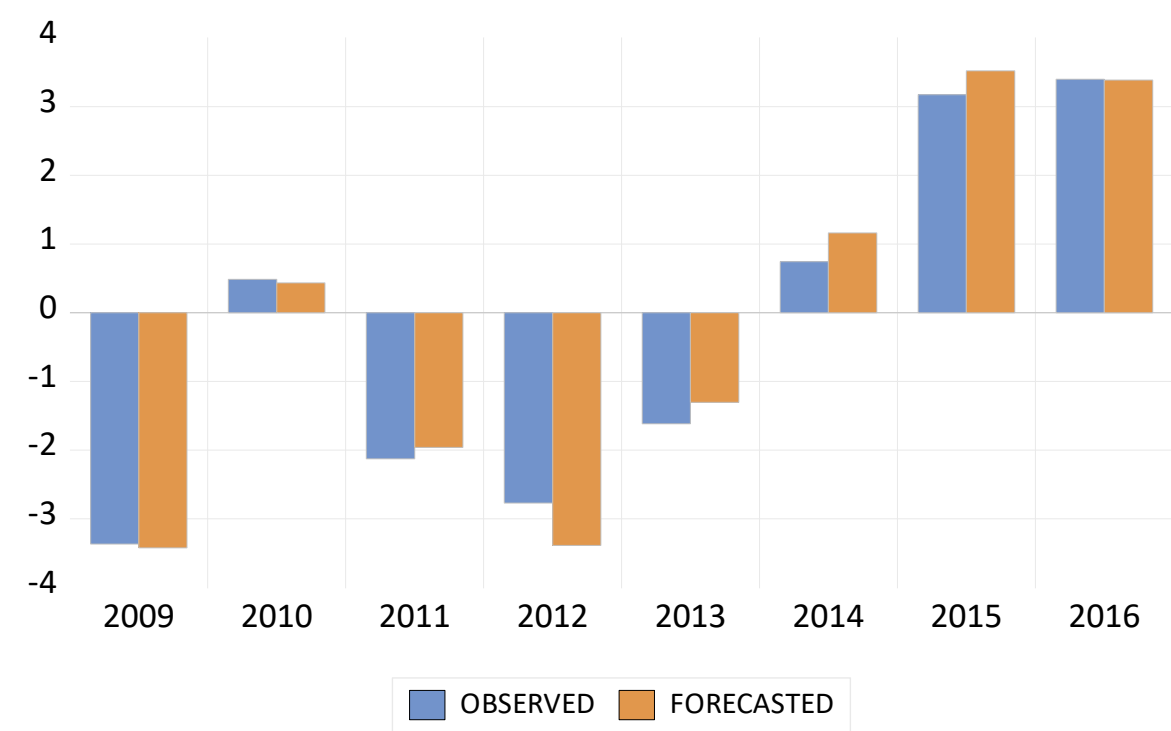

Source: Authors' own elaboration

Figure 5 shows both the observed and the synthetic growth rates of Galicia for the period 2009 to 2016. Except for the years 2009 and 2011, the negative observed values are lower and positive growth rates are higher than in the counterfactual.

Figure 6 presents the previous annual growth rates. In both cases, the value is negative, but the actual rate $(-2.30 \%)$ is clearly lower in absolute terms than that corresponding to the synthetic unit $(-3.91 \%)$.

Figure 7 shows both the actual and the synthetic values of the variation rates of the GDP for Galicia from 1995 to 2016. While most of the actual values are lower before 2008, since then they have been higher than the synthetic estimate of the region's growth. This again supports the idea that fiscal austerity implemented to meet the deficit targets has not involved an evident price in terms of regional economic growth.

To check the robustness of the results, we replicate the analysis, constraining the donor regions to those in which the deviation from the fiscal consolidation targets has been wider (Castilla-La Mancha, Cataluña, Comunidad Valenciana and Murcia). The regional weights that minimize the root mean square prediction error (RMSPE $=0.0071$ ) over the validation period are 0.791 for Cataluña and 0.219 for Castilla-La Mancha. Figure 8 shows the new results. Over the period 2004-2012, the growth of the counterfactual of Galicia is below the actual growth. After 2013, the values are slightly higher, but the positive gap in the counterfactual in recent years does not compensate for the negative gap in 2012. 
Economics: The Open-Access, Open-Assessment E-Journal 13 (2019-42)

Figure 6: Cumulative observed and forecasted GDP growth rates

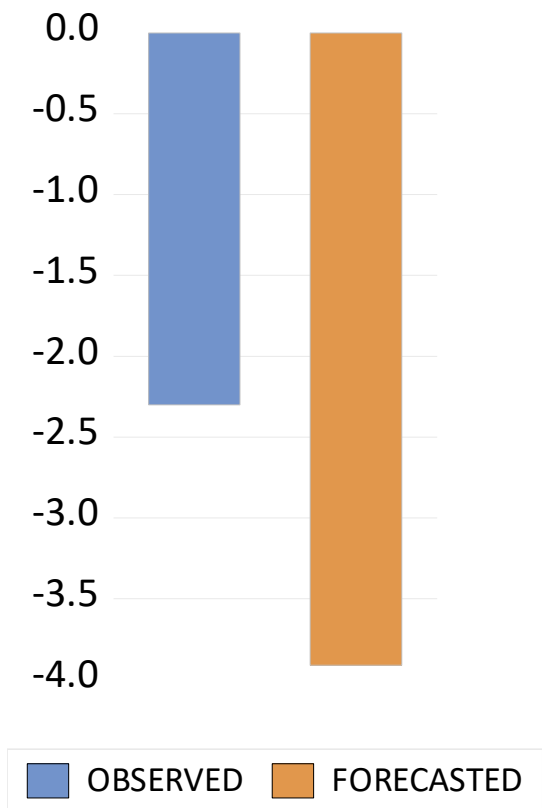

Source: Authors’ own elaboration

Figure 7: Observed and SCM GDP growth rates over the period 1995-2016

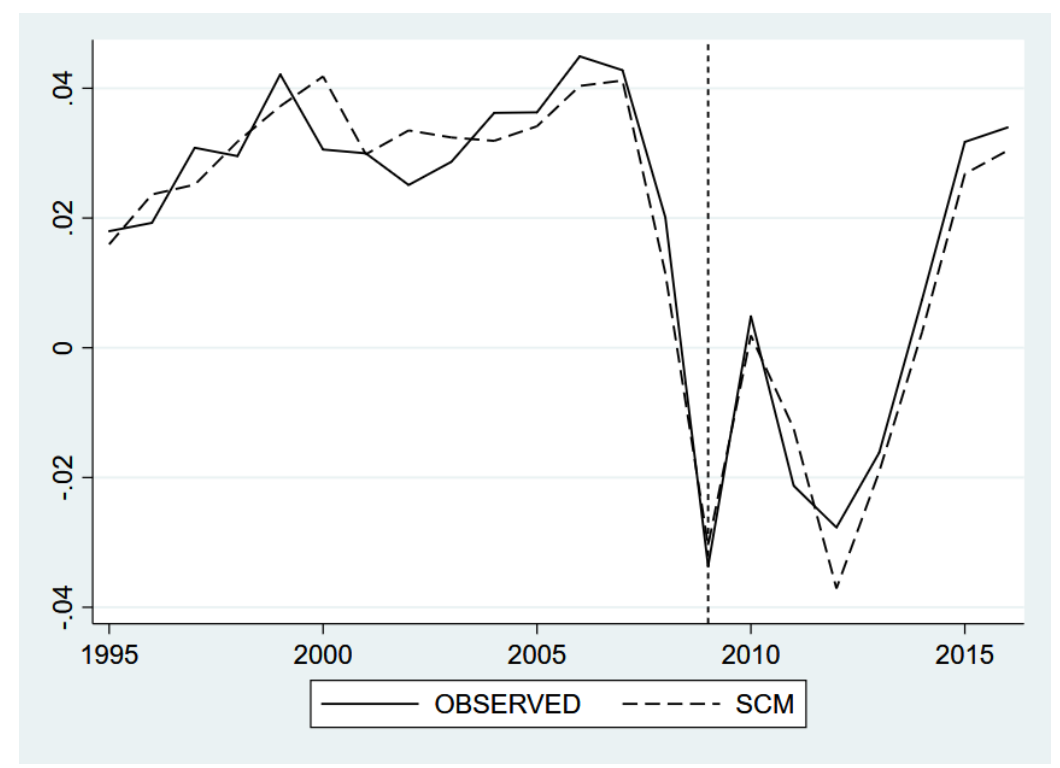

Source: Authors’ own elaboration 
Figure 8: Observed and constrained SCM GDP growth rates over the period 1995-2016

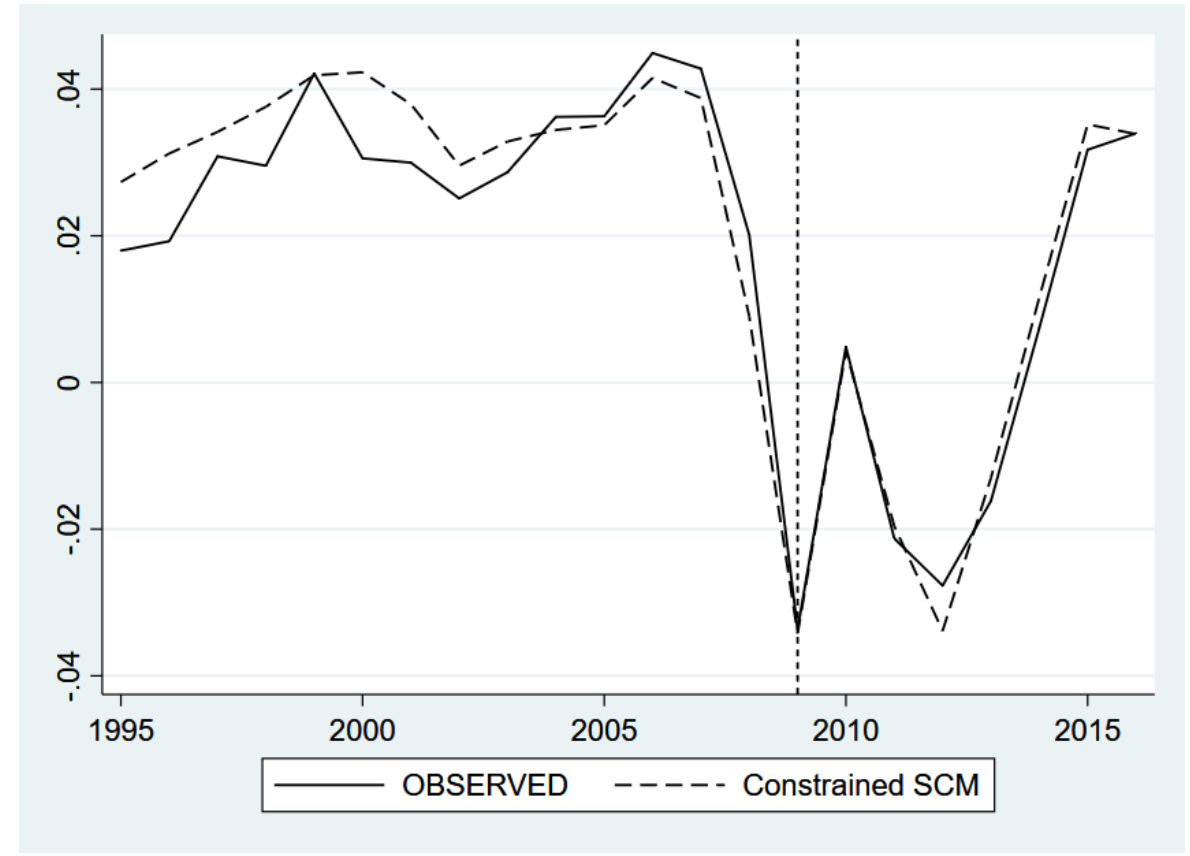

Source: Authors' own elaboration

\section{Conclusions}

Regional governments provide a convenient field to test whether fiscal consolidation involves a price to pay in terms of the short-run GDP growth rate. Given the high fiscal decentralization in Spain, the depth of the effects of the Great Depression on the public accounts at the regional level in Spain and the diversity of commitments to fiscal targets, this country is the best case study among the OECD members.

To perform the test, we focused our attention on the region showing a better performance in terms of compliance of the fiscal targets agreed with the European Commission. In particular, we compare the observed short-run GDP growth rates with two simulations. The first one is based on the estimate of a time-series model relating the GDP dynamics of Galicia and Spain over the period 1995-2008. The second one relies on the more sophisticated synthetic control method (SCM) approach. In both cases, we show that stricter fiscal consolidation has not produced a significant reduction in economic growth. Indeed, the economic performance of Galicia would have been slightly better than expected using both methodologies.

Our interpretation of the results is closely related to the traditional theory of fiscal federalism (Musgrave, 1959). According to it, openness and economic integration of regional economies involve fiscal multipliers that tend to fade. A fiscal stimulus would not work on this scale. Our results show that the opposite is also true: the potentially negative demand effects of a stronger regional fiscal consolidation strategy would be exported to other regions. 
The most relevant policy implication of our results is that decentralization could indeed contribute to the compliance with fiscal consolidation plans on the national scale, reversing the usual arguments on both the common pool's problem affecting fiscal stability in decentralized countries and the challenge involved by "soft budget constraints" and bailout expectations (Goodspeed, 2017). If the negative demand effects of regional fiscal consolidation are mostly exported to other regions, one of the reasons most often argued to delay deficit cuts and compliance with fiscal targets is deactivated.

The smartest strategy for all regions is to cut deficit, getting the benefits and exporting the costs in terms of lower GDP growth rates. But if decentralization is very high and all regions play the same, fiscal consolidation at the country level will tend to be stronger than is centralized countries. In other words, while the total negative effect of fiscal consolidation on national GDP growth rate could be the same than in a centralized country, the incumbents' perceived costs of fiscal adjustments be downward biased and then, fiscal consolidation in the country as a whole could be stronger.

It is tentative to extend this interpretation to supranational areas such as the European Union. First, from an analytical standpoint, the degree of economic integration in supranational areas would be highly relevant to understand cross-national differences in fiscal multipliers. Hence, this factor should be included in the list of control variables in cross-country estimates. Second, from a policy perspective, further progress in economic integration (trade, banking, fiscal flows...) will reduce the positive effects of national fiscal policies, but it will also fade the potential negative effects on GDP growth rates of national fiscal adjustments.

Acknowledgements The authors thank Francisco Pérez, Carlos Hervés, Carlos Cuerpo, and one anonymous reviewer for their suggestions, and Alejandro Domínguez for superb research assistance. A previous version of the paper was discussed in the I GEN Workshop (Ourense, 2018). The authors acknowledge financial support from the Spanish Minister of Science, Innovation and Universities (Grant number AEI/FEDER CSO2017-85024-C2-2-P). Usual disclaimer applies. 


\section{References}

Abadie, A. and Gardezabal, J. (2003). The economic costs of conflict: A case study of the Basque Country. American Economic Review, 93(1), 113 -132. https://www.aeaweb.org/articles?id=10.1257/000282803321455188

Abadie, A., Diamond, A. and Hainmueller, J. (2010). Synthetic control methods for comparative case studies: Estimating the effect of California's tobacco control program. Journal of the American Statistical Association, 105(490), $493-505$. https://doi.org/10.1198/jasa.2009.ap08746

Abadie, A., Diamond, A. and Hainmueller, J. (2015). Comparative Politics and the Synthetic Control Method. American Journal of Political Science, 59(2), 495-510.

https://doi.org/10.1111/ajps.12116

AIReF (2016). Informe sobre el establecimiento de los objetivos individuales de estabilidad presupuestaria y deuda pública para las Comunidades Autónomas.

http://www.airef.es/es/informes-tipo/informe-sobre-el-establecimiento-de-los-objetivosindividuales-de-las-comunidades-autonomas/

Alesina, A. and Ardagna, S. (1998). Tales of fiscal adjustment. Economic Policy, 13(27), 488-545. https://doi.org/10.1111/1468-0327.00039

Alesina, A. and Ardagna, S. (2010). Large changes in fiscal policy: taxes versus spending. Tax Policy and the Economy, 24(1), 35-68.

http://doi.org/10.3386/w15438

Alesina, A., Favero, C. and Giavazzi, F. (2019). Austerity. When it works and when it Doesn't. Princeton University Press, Princeton.

Andrés, J. and Doménech, R. (2013). Fiscal adjustment and economic growth in Europe. BBVA Economic Watch Europe, Madrid.

https://www.bbvaresearch.com/KETD/fbin/mult/130219_Europe_Watch-

Fiscal_adjustment_tcm348-374754.pdf

Attinasi, M.G. and Klemm, A. (2016). The growth impact of discretionary fiscal policy measures. Journal of Macroeconomics, 49, 265-279.

https://doi.org/10.1016/j.jmacro.2016.08.004

Auerbach, A.J. and Gorodnichenko, Y. (2012). Measuring the output responses to fiscal policy. American Economic Journal: Economic Policy, 4(2), 1-27. http://doi.org/10.1257/pol.4.2.1

BBVA Research (2010). Impacto del año Xacobeo en la economía gallega https://www.bbvaresearch.com/KETD/fbin/mult/1003_observatorioregionalespana_tcm348217035.pdf

Blanchard, O.J. and Leigh, D. (2013). Growth forecast errors and fiscal multipliers. American Economic Review, 103(3), 117-120. http://doi.org/10.1257/aer.103.3.117

Blanchard, O. and Cottarelli, C. (2010). Ten commandments for fiscal adjustment in advanced economies. VoxEU.org, 28.

https://voxeu.org/article/ten-commandments-fiscal-adjustment-advanced-economies 
Buti, M. and Pench, L.R. (2012). Fiscal austerity and policy credibility. In Corsetti, G. (eds.) Austerity: Too Much of a Good Thing?, 45-55.

https://voxeu.org/article/fiscal-austerity-and-policy-credibility

Cantalapiedra, C. and Lopez, C. (2013). Las líneas presupuestarias de las comunidades autónomas y el ajuste estructural del gasto. Cuadernos de Información Económica, 231, 17-25.

https://dialnet.unirioja.es/servlet/articulo?codigo $=4122955$

Corsetti, G. Meier, A., and Müller, G. (2012). What Determines Government Spending Multipliers? Economic Policy, 27(72), 521-565. https://doi.org/10.1111/j.1468-0327.2012.00295.x

De Grauwe, P. and Ji, Y. (2013). From Panic Driven Austerity to Symmetric Macroeconomic Policies in the Eurozone. JCMS: Journal of Common Market Studies, 51(S1), 31-41.

https://doi.org/10.1111/jcms.12042

De Mello, L. (2013). What Can Fiscal Policy Do in the Current Recession? A Review of Recent Literature and Policy Options. Review of Public Economics, 204, 113-139.

http://www.ief.es/comun/Descarga.cshtml?ruta= /docs/destacados/publicaciones/revistas/hpe/204 _Art5.pdf

Fatás, A. and Summers, L.H. (2018). The permanent effects of fiscal consolidations. Journal of International Economics, 112, 238-250. https://doi.org/10.1016/j.jinteco.2017.11.007

Gechert, S. and Will, H. (2012). Fiscal multipliers: A meta regression análisis. Working Paper 2012/97, Institut für Makroökonomie und Konjunkturforschung (IMK), Hans-Böckler-Stiftung. http://www.boeckler.de/pdf/p_imk_wp_97_2012.pdf

Giavazzi, F. and Pagano, M. (1990). Can severe fiscal contractions be expansionary? Tales of two small European countries. NBER Macroeconomics Annual, 5, 75-111. http://doi.org/10.3386/w3372

Goodspeed, T.J. (2017). Bailouts and Soft Budget Constraints in Decentralized Government: A Synthesis and Survey of an Alternative View of Intergovernmental Grant Policy. Hacienda Pública Española / Review of Public Economics 220: 113-134. http://www.ief.es/docs/destacados/publicaciones/revistas/hpe/221_Art5.pdf

Hernández de Cos, P. and Moral-Benito, E. (2016). Fiscal multipliers in turbulent times: the case of Spain. Empirical Economics, 50(4), 1589-1625. https://link.springer.com/article/10.1007/s00181-015-0969-0

Hooghe, L., Marks, G., Schakel, A., Chapman-Osterkatz, S., Niedzwiecki, S. and Shair-Rosenfield, S. (2016). Measuring Regional Authority: A Postfunctionalist Theory of Governance: Volume I. Oxford University Press, Oxford.

Lago-Peñas, S. (2001). Crecimiento y convergencia: apuntes para un balance de la economía gallega en las dos últimas décadas. Revista de Estudios Regionales, 61, 191-214.

https://dialnet.unirioja.es/servlet/articulo?codigo $=252077$

Lago-Peñas, S. (2017). Fiscal consolidation: Favorable economic conditions threatened by political uncertainty. SEFO, 6(6), 21-29.

https://www.funcas.es/Publicaciones/Detalle.aspx?IdArt=23383 
Lago-Peñas, S. and Vaquero-García, A. (2016). El comportamiento del déficit y la deuda en las Comunidades Autónomas en el período 2005-2015. Mediterráneo Económico, 30, 429-445. http://www.publicacionescajamar.es/publicaciones-periodicas/mediterraneoeconomico/mediterraneo-economico-30-financiacion-autonomica-problemas-del-modelo-ypropuestas-de-reforma/760/

Lago-Peñas, S., Fernández-Leiceaga, X. and Vaquero-García, A. (2017). Spanish fiscal federalism: A successful (but still unfinished) process. Environment and Planning C: Politics and Space, 35(8), 1509-1525. https://doi.org/10.1177\%2F2399654417704663

Lago-Peñas, S., Martinez-Vazquez, J. and Sacchi, A. (2019). Fiscal stability during the Great Recession: Putting decentralization design to the test. Regional Studies. https://www.tandfonline.com/doi/full/10.1080/00343404.2019.1637836?scroll=top\&needAccess=t rue

MINHAP (2012). Actualización del Programa de Estabilidad 2012-2015. http://www.hacienda.gob.es/Documentacion/Publico/CDI/Programas\%20de\%20Estabilidad/Progr ama\%20de\%20Estabilidad\%202012-2015.pdf

Musgrave, R. (1959). The Theory of Public Finance: A Study in Public Economy. McGraw-Hill, New York.

Nickel, C. and Tudyka, A. (2013). Fiscal stimulus in times of high debt: Reconsidering multipliers and twin deficits. Journal of Money, Credit and Banking, 46(7), 1313-1344. https://doi.org/10.1111/jmcb.12148

Rodríguez, L. and Cuerpo, C. (2018). Some elements for a revamped fiscal framework for Spain. AIREF Working Paper WP2018/3. https://www.airef.es/en/document-center/working-papers/working-paper-3-2018-some-elementsfor-a-revamped-fiscal-framework-for-spain/

Spilimbergo, M.A., Symansky, M.S.A., Cottarelli, M.C. and Blanchard, O.J. (2009). Fiscal policy for the crisis. International Monetary Fund. https://www.imf.org/external/pubs/ft/spn/2008/spn0801.pdf

Warmedinger, T., Westphal, C. and De Cos, P.H. (2015). Fiscal multipliers and beyond. Hacienda Pública Española / Review of Public Economics, 215, 139-168.

http://www.ief.es/docs/destacados/publicaciones/revistas/hpe/215_Art6.pdf

\section{Data sources}

AIReF (2018). Autoridad Independiente de Responsabilidad Fiscal (www.airef.es).

BEDE (2018). Boletín Estadístico del Banco de España. https://www.bde.es/webbde/es/estadis/infoest/bolest.html

DataComEx (2018). Estadística de comercio exterior extranjero http://datacomex.comercio.es/principal_comex_es.aspx

DataInvEx (2018). Estadísticas de inversión extranjera en España. http://datainvex.comercio.es/principal_invex.aspx 
EC (2018). EC Database

http://ec.europa.eu/regional_policy/en/information/publications/working-papers/2011/a-newregional-competitiveness-index-theory-methods-and-findings

INE (2018). Contabilidad Regional de España.

https://www.ine.es/

FEDEA (2018). Documentos de Economía Regional y Urbana.

https://www.fedea.net/documentos-economia-regional-y-urbana/

IVIE (2018a). Base de datos de capital humano y desarrollo humano.

https://www.ivie.es/es_ES/bases-de-datos/capital-humano-y-desarrollo-humano/capitalhumano/base-de-datos-capital-humano/

IVIE (2018b). El stock y los servicios del capital en España y su distribución territorial y sectorial (1964-2016).

http://www.fbbva.es/TLFU/microsites/stock09/fbbva_stock08_index.html

MINHAP (2018). Database of Ministry of the Treasury and Public Administrations

https://serviciostelematicos.minhap.gob.es/cimcanet/aspx/consulta/consulta.aspx 


\section{Economics}

Please note:

You are most sincerely encouraged to participate in the open assessment of this article. You can do so by either recommending the article or by posting your comments.

Please go to:

http://dx.doi.org/10.5018/economics-ejournal.ja.2019-42

The Editor 